\title{
Effect of diets with different energy concentrations on growth performance, carcass characteristics and meat chemical composition of broiler chickens in dry tropics
}

\author{
F. Infante-Rodríguez², J. Salinas-Chavira ${ }^{\text {* }}$, M. F. Montaño-Gómez², O. M. Manríquez-Nuñez², \\ V. M. González-Vizcarra², O. F. Guevara-Florentino ${ }^{2}$ and J. A. Ramírez De León ${ }^{1}$
}

\begin{abstract}
Background: Diets with increasing levels of energy were fed for 42 days to 200, 1-day old male broiler chickens to evaluate growth performance, carcass characteristics and chemical composition of meat. The study was performed in the subtropical area of northeastern Mexico. Treatments diets $(T)$ for starter and finisher phases had apparent metabolizable energy (AME; kcal/kg) of: 2960 and 3040 (T1); 3000 and 3080 (T2); 3040 and 3120 (T3); 3080 and 3160 (T4), respectively. Within each of the growing phases the four treatment diets were formulated to contain similar levels of crude protein, amino acids, and other nutrients. In a completely randomized design, birds were allocated to the four treatments with five replicates (floor pens) of 10 birds each. The trial was divided in two phases (starter and finisher) of 21 days each (42 days total).

Results: Weight gain was not influenced by energy level; however, feed conversion efficiency was improved in the diets with 3040 and $3120 \mathrm{kcal} / \mathrm{kg}$ AME (T3; P < 0.05). There was no influence of treatment on total carcass weight or carcass cuts $(P>0.05)$. Meat from breast muscle had similar crude protein percentages among treatments; ether extract was higher in $\mathrm{T} 1$ than $\mathrm{T} 4(\mathrm{P}<0.05)$. The percentages of water, ether extract, ash and crude protein in thigh meat were not significantly different $(P>0.05)$ among treatments.
\end{abstract}

Conclusions: For this study carried out in a dry tropical area, the moderate increase in dietary energy concentration (diet with 3040 and $3120 \mathrm{kcal} / \mathrm{kg} \mathrm{AME}$, T3) enhanced feed conversion efficiency of broiler chickens.

Keywords: Energy level, Growth performance, Carcass, Meat composition, Broiler chicken

\section{Background}

Poultry constituted $63 \%$ of animal production in Mexico: $33.5 \%$ was contributed by production of broiler chickens, almost $29 \%$ by egg production and $0.1 \%$ by production of turkeys (Unión Nacional de Avicultores (UNA) 2015). In Mexico, the cost of feed plus the cost of the chicks represents approximately $90 \%$ of broiler production costs (Unión Nacional de Avicultores (UNA) 2015). Diets for

\footnotetext{
*Correspondence: jsalinasc@hotmail.com

${ }^{1}$ Facultad de Medicina Veterinaria y Zootecnia, Universidad Autónoma de Tamaulipas, Km 5.5 Carretera Victoria, Mante, C.P. 87000 Ciudad Victoria, Tamaulipas, Mexico

Full list of author information is available at the end of the article
}

broilers are based on grains such as sorghum or corn plus soybean meal, which have been expensive in recent years. In this sense, improvements in feed efficiency reduce production cost in broiler chicken production (Branson and Hernández 2012).

Broiler meat is an important protein source for consumers. In Mexico, per capita consumption in 2014 was $29.3 \mathrm{~kg}$ of broiler chicken meat. Low and medium income households prefer "dark meat" (broiler hindquarters), while consumers with higher incomes prefer cuts of "white meat" (breast) and other value-added chicken products (Branson and Hernández 2012). A greater yield of cuts of higher market value (breast) 
is desirable. In addition, consumers prefer meat with lower fat content mainly due to health concerns. There are some reports on the influence of nutrient concentration in diet on growth performance or carcass yield; however, there is limited information of influence on meat (breast and thigh + drumstick) chemical composition, in particular for broiler chicken production under tropical conditions.

Increasing the energy and protein density of diets for broiler chickens has given inconclusive results. A preliminary study (Waldroup et al. 1990) found no effect of energy concentration of diets on growth performance or abdominal fat, although higher energy density increased dressing percentage in females, but not in males. Similarly, others found no effect of dietary energy level on carcass yield or abdominal fat (Nunes et al. 2012; Duarte et al. 2014). In contrast, Marcu et al. (2012a) reported improved growth performance and carcass yield for the main cuts of broiler chickens fed diets with high energy and protein levels. Marcu et al. (2013) found that increasing dietary energy and protein elevated breast weight and muscle mass, and reduced fat content, while reducing nutrient levels decreased protein content and elevated fat content in pectoral muscle. In contrast, Ferreira et al. (2015) produced meat with less fat in broiler chickens fed low energy diets, although growth was decreased. Several factors could have influenced the results of growth performance, carcass yield of cuts or meat chemical composition of broiler chickens fed diets with different nutrient density; one of them was genotype of broiler chickens. Kim et al. (2012) reported different responses to energy concentration with different strains of broiler chickens.

The continuous improvement in the genetics of broiler chickens has enhanced productive and carcass characteristics, including carcass leanness. Research on broiler nutrition and feeding must also continue to synergize with improvements in genetic potential. This research is also important in areas where the climatic conditions may influence the productive performance, carcass yield and meat chemical composition. In northeastern Mexico the standard diets for starter and finisher phases for broiler chickens contain 2994 and $3081 \mathrm{kcal} / \mathrm{kg} \mathrm{ME}$, respectively. An energy increase in the diets to 3013 and $3111 \mathrm{kcal} / \mathrm{kg}$ ME for starter and finisher phases improved growth performance of broiler chickens (Orduña-Hernández et al. 2016); although they did not explore higher energy levels and did not study carcass characteristics. The objective of this research was to assess productive performance, carcass yield of major cuts and chemical composition of meat from breast and thigh of broiler chicks in a 42-days feeding trial in the subtropical area of northeastern Mexico.

\section{Methods}

\section{Description of the study area}

This study was carried out at the Facultad de Medicina Veterinaria y Zootecnia, Universidad Autónoma de Tamaulipas, in Ciudad Victoria, Tamaulipas (subtropical area in northeastern Mexico). The area is located at $23^{\circ} 44^{\prime} 06^{\prime \prime} \mathrm{N}$ and $97^{\circ} 09^{\prime} 50^{\prime \prime} \mathrm{W}$, at an altitude of $340 \mathrm{~m}$. The mean annual rainfall is $900 \mathrm{~mm}$, and the average temperature is $25^{\circ} \mathrm{C}$ (INEGI. Instituto Nacional de Estadística, Geografía e Informática 2006). These climatic characteristics are typical for dry tropics. During the experiment average minimum and maximum temperatures averaged 23.2 and $33.6{ }^{\circ} \mathrm{C}$, respectively.

Management and feeding of experimental broiler chickens All procedures involving animal care and management were in accordance with and approved by the Bioethics Committee of the Facultad de Medicina Veterinaria y Zootecnia, Universidad Autónoma de Tamaulipas.

Two hundred, 1-day-old male Ross broiler chickens weighing $42 \mathrm{~g}$ on average were obtained from a commercial hatchery. Each treatment (or diet) included 50 birds randomly assigned with five replications of ten animals each. During the entire experiment, birds were housed in 20 floor pens with wood shavings as litter. Twenty-four hours of light per day were provided during the entire trial. Each pen had an automatic drinker and a feeder filled manually. Space allocation was at 10 birds per square meter. Water and feed were offered ad libitum. Birds were vaccinated on day 7 of the trial against fowlpox (by wing puncture) and against Newcastle (ocular) using the La Sota strain.

The chickens were raised following standard commercial practice. Two feeding phases were used: 1-21 and 22-42 days of age, for starter and finisher phases, respectively. There were four treatments $(\mathrm{T})$. For starter and finisher the apparent metabolizable energy (AME) levels were: 2960 and 3040 (T1); 3000 and 3080 (T2); 3040 and 3120 (T3); 3080 and $3160 \mathrm{kcal} / \mathrm{kg}$. Dietary AME was increased by augmenting vegetable oil in the diet, with small adjustments to the amounts of sorghum grain and soybean meal to keep the levels of $\mathrm{CP}$ and other nutrients the same across diets. All diets were prepared according to National Research Council (NRC) (1994) poultry recommendations and are shown in Tables 1 and 2 .

During the feeding trial, body weight and feed intake were measured weekly and feed conversion efficiency (feed intake/weight gain) was calculated. At the end of the trial, two birds per cage, selected at random, were sacrificed by cervical dislocation (Mexican official law NOM 033-ZOO-1995) for carcass determinations and chemical composition of breast and thigh meat. Carcass weight without viscera was used to estimate hot carcass 
Table 1 Experimental diets for the starter phase (\% as-fed basis)

\begin{tabular}{lllll}
\hline & T1 & T2 & T3 & T4 \\
\hline Ingredient & & & & \\
Sorghum, grain & 60.9 & 59.9 & 58.9 & 57.8 \\
Soybean meal & 33.3 & 33.5 & 33.7 & 33.9 \\
Vegetable oil & 1.8 & 2.6 & 3.4 & 4.2 \\
Premix & 4.0 & 4.0 & 4.0 & 4.0 \\
Total & 100 & 100 & 100 & 100 \\
Calculated analysis & & & & \\
AME, kcal/kg & 2960 & 3000 & 3040 & 3080 \\
CP (\%) & 21.4 & 21.4 & 21.4 & 21.4 \\
Lysine (\%) & 1.1 & 1.1 & 1.1 & 1.1 \\
Methionine (\%) & 0.5 & 0.5 & 0.5 & 0.5 \\
Ca (\%) & 1.0 & 1.0 & 1.0 & 1.0 \\
P (\%) & 0.7 & 0.7 & 0.7 & 0.7 \\
\hline
\end{tabular}

a Concentrated premix for starter phase broiler chickens. Contained: calcium mono-ortho phosphate, calcium carbonate, salt, growth promoter (BMD and 3-nitro), coccidiostat (sodium monensin), mineral oil, ethoxyquin, vitamin $\mathrm{A}$ acetate, vitamin $\mathrm{D}_{3}$, vitamin $\mathrm{E}$ acetate, vitamin $\mathrm{K} 3$, riboflavin (B2), vitamin $\mathrm{B}_{12}$, niacin, D-calcium pantotenate, choline chloride, butylated hydroxytoluene (BHT). Premix calculated to contain: calcium, 21.40\%; total phosphorus, $8.10 \%$; sodium, 3.40\%; L-lysine hydrochloride, $0.80 \%$; DL-methionine, $4.15 \%$

Table 2 Experimental diets for the finisher phase (\% asfed basis)

\begin{tabular}{|c|c|c|c|c|}
\hline & T1 & $\mathrm{T} 2$ & T3 & T4 \\
\hline \multicolumn{5}{|l|}{ Ingredient } \\
\hline Sorghum, grain & 67.6 & 66.6 & 65.6 & 64.6 \\
\hline Soybean meal & 26 & 26.2 & 26.4 & 26.6 \\
\hline Vegetable oil & 2.1 & 2.9 & 3.7 & 4.5 \\
\hline Premix ${ }^{a}$ & 4 & 4 & 4 & 4 \\
\hline Pigment & 0.3 & 0.3 & 0.3 & 0.3 \\
\hline Total & 100 & 100 & 100 & 100 \\
\hline \multicolumn{5}{|l|}{ Calculated analysis } \\
\hline AME (kcal/kg) & 3040 & 3080 & 3120 & 3160 \\
\hline $\mathrm{CP}(\%)$ & 18.7 & 18.7 & 18.7 & 18.7 \\
\hline Lysine (\%) & 1.0 & 1.0 & 1.0 & 1.0 \\
\hline Methionine (\%) & 0.5 & 0.5 & 0.5 & 0.5 \\
\hline $\mathrm{Ca}(\%)$ & 0.9 & 0.9 & 0.9 & 0.9 \\
\hline $\mathrm{P}(\%)$ & 0.7 & 0.7 & 0.7 & 0.7 \\
\hline
\end{tabular}

a Concentrated premix for finisher phase broiler chickens. Contained: calcium mono-ortho phosphate, calcium carbonate, salt, growth promoter (BMD and 3-nitro), coccidiostat (sodium monensin), mineral oil, ethoxyquin, vitamin $A$ acetate, vitamin $D_{3}$, vitamin $E$ acetate, vitamin $K 3$, riboflavin (B2), vitamin $B_{12}$, niacin, calcium D-pantotenate, choline chloride, $\mathrm{BHT}$. Premix calculated to contain: calcium, $19.80 \%$; total phosphorus, $7.30 \%$; sodium, 3.70\%; L-lysine hydrochloride, $4.33 \%$; DL-methionine, $5.15 \%$

yield. Then, the carcass was dissected for main cuts: breast, thighs plus drumsticks, wings, and back; back fat was also weighed. A sample of left side of breast and thigh from each carcass was obtained and frozen in nylon bags until laboratory analyses were performed. Muscle samples were analyzed for dry matter (oven at $105{ }^{\circ} \mathrm{C}$ for $24 \mathrm{~h}$ ), ash (furnace at $550{ }^{\circ} \mathrm{C}$ for $3 \mathrm{~h}$ ), ether extract and crude protein percentages (AOAC 1990).

\section{Statistical analyses}

A completely randomized design with 4 treatments and 5 replicates was used in the statistical analysis. The treatments evaluated were the dietary energy levels. For growth performance (weight gain, feed intake and feed conversion efficiency) the replicate was the average for all broiler chickens in each pen. For carcass evaluation and meat chemical composition the replicate was the average of two birds (selected at random) per pen. An analysis of variance with Tukey's test for mean comparisons was applied. Statistical significance was declared at $\mathrm{P}<0.05$. For statistical analyses the GLM procedures of SAS (2007) were used.

\section{Results}

\section{Growth performance}

Broiler chicken productive performance is shown in Table 3. For the starter phase, there was no effect $(\mathrm{P}>0.05)$ of dietary energy concentration on weight gain. Broiler chickens in T3 had lower feed intake and better feed conversion efficiency than those in $\mathrm{T} 1$ and $\mathrm{T} 2(\mathrm{P}<0.05)$. For the finisher phase, there was no effect $(P>0.05)$ of energy level on weight gain. Broilers in T3 had lower feed intake than those in T2. Also broilers in $\mathrm{T} 3$ had better feed conversion efficiency than those in $\mathrm{T} 1$ and T2 $(\mathrm{P}<0.05)$. For the 42-day feeding period, there was no treatment effect $(\mathrm{P}>0.05)$ on weight. Broiler chickens in T3 had lower feed intake than those in T1 and $\mathrm{T} 2$ and showed better feed conversion efficiency than those in T1, T2 and T4 $(\mathrm{P}<0.05)$.

Table 3 Performance measures of broiler chickens (cumulative average per bird)

\begin{tabular}{llllll}
\hline & T1 & T2 & T3 & T4 & SEM \\
\hline Starter phase (1-21 days) & & & & & \\
Weight gain (g) & 750 & 764 & 766 & 740 & 18.74 \\
Feed intake (g) & $1207^{\mathrm{a}}$ & $1224^{\mathrm{a}}$ & $1080^{\mathrm{b}}$ & $1124^{\mathrm{ab}}$ & 36.10 \\
Feed conversion efficiency & $1.61^{\mathrm{a}}$ & $1.61^{\mathrm{a}}$ & $1.41^{\mathrm{b}}$ & $1.52^{\mathrm{ab}}$ & 0.05 \\
Finisher phase (22-42 days) & & & & & \\
$\quad$ Weight gain (g) & 1723 & 1757 & 1844 & 1719 & 46.94 \\
Feed intake (g) & $3556^{\mathrm{ab}}$ & $3634^{\mathrm{a}}$ & $3417^{\mathrm{b}}$ & $3432^{\mathrm{ab}}$ & 68.85 \\
Feed conversion efficiency & $2.07^{\mathrm{a}}$ & $2.08^{\mathrm{a}}$ & $1.85^{\mathrm{b}}$ & $2.00^{\mathrm{ab}}$ & 0.05 \\
Total trial (1-42 days) & & & & & \\
$\quad$ Weight gain (g) & 2473 & 2520 & 2609 & 2459 & 57.35 \\
Feed intake (g) & $4763^{\mathrm{ab}}$ & $4858^{\mathrm{a}}$ & $4497^{\mathrm{c}}$ & $4556^{\mathrm{bc}}$ & 76.10 \\
Feed conversion efficiency & $1.93^{\mathrm{a}}$ & $1.93^{\mathrm{a}}$ & $1.73^{\mathrm{b}}$ & $1.86^{\mathrm{a}}$ & 0.04 \\
\hline
\end{tabular}

abc Different superscripts in a row differ $(P<0.05)$ 


\section{Carcass characteristics}

Results of carcass characteristics of broilers chickens are shown in Table 4. There was no influence of treatment on weight of carcass, breast, drumstick plus thighs, wings and back fat $(\mathrm{P}>0.05)$. Animals fed T3 and T4 had greater $(\mathrm{P}<0.05)$ back weight than those in $\mathrm{T} 1$. Carcass yield was similar among treatments $(\mathrm{P}>0.05)$.

\section{Proximate composition of breast and thigh meat}

Results of chemical composition of broiler chicken breast and thigh meat are shown in Table 5. Breast muscle had similar $(\mathrm{P}>0.05)$ crude protein percentage among treatments. Water percentage was higher in T3 than T4; ash content was higher in $\mathrm{T} 3$ than $\mathrm{T} 2$; ether extract was higher in breast muscle of birds in T1 than those in T4 $(\mathrm{P}<0.05)$. Thigh muscle had similar $(\mathrm{P}>0.05)$ water, ether extract, ash and crude protein percentages among treatments $(\mathrm{P}>0.05)$.

\section{Discussion}

\section{Growth performance}

Carbohydrates in grains are the main source of energy in broilers diets; however, lipids are included in these diets to cover the energy requirements of birds for maximum growth performance (National Research Council (NRC) 1994). In the current study the increase in dietary energy concentration was achieved by increasing the amount of vegetable oil. Energy concentration did not influence broiler chicken weight gain; however, feed conversion was improved using diet T3, which maintained weight gain with lower feed intake. Other studies are in agreement with this finding (Jafarnejad and Sedegh 2011; Ferreira et al. 2015; Orduña-Hernández et al. 2016). In different reports on broiler chickens, there is no clear indication about the effects of energy level in diet on weight gain, feed intake or feed efficiency. In studies using diets similar to those of the current study, Tancharoenrat and Ravindran (2014) observed that an increase

Table 4 Carcass characteristics of broiler chickens

\begin{tabular}{llllll}
\hline & T1 & T2 & T3 & T4 & SEM \\
\hline Live weight (g) & 2781 & 2812 & 2879 & 2852 & 72.95 \\
Hot carcass weight (g) & 1956 & 2012 & 2068 & 2046 & 58.66 \\
Breast weight (g) & 724 & 745 & 762 & 744 & 26.72 \\
Thigh + drumstick weight (g) & 604 & 608 & 628 & 627 & 16.14 \\
Wings weight (g) & 221 & 218 & 221 & 225 & 6.18 \\
Back weight (g) & $355^{\mathrm{b}}$ & $382^{\mathrm{ab}}$ & $396^{\mathrm{a}}$ & $412^{\mathrm{a}}$ & 12.62 \\
Back fat weight (g) & 28.50 & 29.50 & 34.00 & 31.30 & 2.97 \\
Carcass yield (\%) & 70.32 & 71.57 & 71.75 & 71.76 & 0.63 \\
\hline
\end{tabular}

ab Different superscripts in a row differ $(P<0.05)$
Table 5 Chemical composition of breast and thigh muscles (wet-basis)

\begin{tabular}{lccccc}
\hline & T1 & T2 & T3 & T4 & SEM \\
\hline Breast & & & & & \\
Water (\%) & $74.17^{\mathrm{ab}}$ & $74.48^{\mathrm{ab}}$ & $75.09^{\mathrm{a}}$ & $74.11^{\mathrm{b}}$ & 0.31 \\
Dry matter (\%) & $25.83^{\mathrm{ab}}$ & $25.52^{\mathrm{ab}}$ & $24.91^{\mathrm{b}}$ & $25.89^{\mathrm{a}}$ & 0.31 \\
Ash (\%) & $3.95^{\mathrm{ab}}$ & $3.69^{\mathrm{b}}$ & $4.28^{\mathrm{a}}$ & $4.02^{\mathrm{ab}}$ & 0.11 \\
Ether extract (\%) & $1.85^{\mathrm{a}}$ & $1.15^{\mathrm{b}}$ & $1.50^{\mathrm{ab}}$ & $1.22^{\mathrm{b}}$ & 0.20 \\
Crude protein (\%) & 23.88 & 23.93 & 22.62 & 23.62 & 0.52 \\
Thigh & & & & & \\
Water (\%) & 77.46 & 77.25 & 77.66 & 77.08 & 0.43 \\
Dry matter (\%) & 22.54 & 22.75 & 22.34 & 22.92 & 0.43 \\
Ash (\%) & 1.08 & 1.04 & 1.20 & 1.22 & 0.06 \\
Ether extract (\%) & 2.13 & 2.64 & 2.73 & 2.67 & 0.26 \\
Crude protein (\%) & 19.47 & 19.20 & 19.60 & 19.81 & 0.33 \\
\hline
\end{tabular}

ab Different superscripts in a row differ $(P<0.05)$

in energy level improved weight gain and feed conversion with no effect on feed intake, while Kim et al. (2012) observed reduced feed intake with higher dietary energy. In studies with energy levels lower than those used in the present study, higher dietary ME improved broiler growth performance (Aftab 2009; Ullah et al. 2012).

For the present study, energy level in diet did not influence broilers' weight; however, feed intake was reduced. In contrast, Houshmand et al. (2011) found that broiler chickens fed low energy diets were heavier than those on the standard diet. Tooci et al. (2009) compared concentrate diets (3010, 3150 and $3200 \mathrm{kcal} / \mathrm{kg}$ ME respectively for starter, grower and finisher phases) versus diluted diets $(2800 \mathrm{kcal} / \mathrm{kg} \mathrm{ME})$ and reported that feed intake of broiler chickens was not influenced by energy content in diets, but concentrate diets improved weight gain and feed conversion. In addition to energy, amino acid levels in diet also influenced growth performance of broiler chickens. Zhai et al. (2014) reported that low energy diet with high amino acid levels depressed broilers' feed intake and weight gain. Broiler chickens fed low energy diet with low amino acids had similar growth performance to those in high energy diets.

\section{Carcass characteristics}

In the current study dietary energy level did not influence processed carcass weight, breast, drumstick + thighs, wings and back fat weight or carcass yields. Others have reported similar responses in broiler chickens fed different energy levels (Nunes et al. 2012; Kim et al. 2012). In contrast, higher energy and protein diets increased yield of breast (Marcu et al. 2013), weight of carcass and yields of breast and thigh muscle; whereas drumsticks, wings and other carcass components (head, neck, back 
and legs) were reduced (Marcu et al. 2012b). Marcu et al. (2012a) also showed that diets for broilers having extra energy and protein improved carcass yield in females, but not in males. For both genders, breast and drumstick were improved by extra energy and protein; thigh was not influenced by energy level, but the high energy reduced yield of wings in females. Starter, grower and finisher diets had 3026, 3142 and $3196 \mathrm{kcal} / \mathrm{kg}$ of ME for the control group; while for the extra energy group, the respective values of diets were 3281,3439 and $3483 \mathrm{kcal} /$ $\mathrm{kg}$ of ME. Zhao et al. (2008) found that carcass, breast, thigh and abdominal fat were increased with higher dietary energy and lysine. The optimum growth and carcass performance were obtained at a dietary energy of 3300 versus $3099 \mathrm{kcal} / \mathrm{kg} \mathrm{ME}$; the levels of dietary lysine were $1.2 \%$ from 0 to 3 weeks of age and 1.1\% from 4 to 6 weeks of age. Rosa et al. (2007) used diets with 2950, 3200 and $3400 \mathrm{kcal} / \mathrm{kg} \mathrm{ME}$, but found no effect on carcass yield, breast or back fat, although the increase in energy concentration depressed yield of thigh + drumstick and increased abdominal fat. Also Wang et al. (2014) found that broiler chickens fed extra energy and amino acids levels, showed increased abdominal fat, while weight of the carcass cuts were not affected. Milošević et al. (2013) reported that increased energy density with continuous illumination increased abdominal fat.

\section{Proximate composition of breast and thigh meat}

In the present study the increase in energy level of the diet had no effect on crude protein percentage in breast muscle, whereas T1 treatment had more lipids in meat from breast than T4. Thigh lipid percentage was not influenced by energy level and protein percentage was greater in T3 than T2. Marcu et al. (2012b) reported that reducing dietary energy level lowered crude protein and increased lipid content of broiler breast and thigh muscle. Marcu et al. (2013) fed broiler diets with 2950, 3100 or $3250 \mathrm{kcal} / \mathrm{kg} \mathrm{ME}$, and reported quadratic effects for lipid and crude protein content of breast that were maximized at $3100 \mathrm{kcal} / \mathrm{kg} \mathrm{ME}$ and were reduced when dietary energy was lower or higher. These results suggest that an increase in dietary energy level for broiler chickens may not increase meat lipids in pectoral muscle.

Ferreira et al. (2015) found different effects and reported lower intramuscular fat content in meat from birds fed diets with lower energy level. Rosa et al. (2007) reported that carcass chemical composition changes in different genetic groups; however, for commercial Ross 308 broilers there was reduced crude protein and increased lipid in carcass with increased dietary energy level in broilers. Others found no effect of dietary energy level on chemical composition of carcass muscle of broilers (Corduk et al. 2007; Gómez-Rosales et al. 2012).

\section{Conclusions}

Body weight gain was not influenced by energy level in diets for broiler chickens; however, there was improved feed conversion efficiency in treatment 3, where 3040 and $3120 \mathrm{kcal} / \mathrm{kg}$ AME were fed in the starter and finisher diets, respectively. Weights of carcass and main cuts (breast, thigh + drumsticks and wings) were not influenced by dietary energy level. For breast muscle, crude protein percentage was not influenced by dietary treatments, although lipid percentage was higher when feeding the low energy diets (T1) compared to the T4 high energy diets. For thigh muscle, lipid or crude protein percentages were not influenced by dietary treatments. In this study conducted in a subtropical area, the moderate increase in dietary energy concentration (diet T3) enhanced feed conversion efficiency of broiler chickens.

\section{Abbreviations \\ T: treatments; AME: apparent metabolizable energy; ME: metabolizable energy; CP: crude protein; Ca: calcium; P: phosphorus.}

\section{Authors' contributions}

$\mathrm{Fl}-\mathrm{R}$ performed the study as part for his research of doctoral degree. JS-C directed the study, and drafted the manuscript. MFM-G contributed with the data analysis and interpretation, also revised the manuscript. OMM-N and VMG-V added important intellectual contribution for the research and for the manuscript preparation, OFG-F designed and conducted the animal feeding management and revised the manuscript. JARDeL had important scientific contribution for the manuscript preparation. All authors read and approved the final manuscript.

\section{Author details}

1 Facultad de Medicina Veterinaria y Zootecnia, Universidad Autónoma de Tamaulipas, Km 5.5 Carretera Victoria, Mante, C.P. 87000 Ciudad Victoria, Tamaulipas, Mexico. ${ }^{2}$ Instituto de Investigaciones en Ciencias Veterinarias, Universidad Autónoma de Baja California, Mexicali, Baja California, Mexico.

\section{Acknowledgements}

The authors thank the technical support for the laboratory analyses of samples, of María Sabina Hernández Morales and Graciana Walle Aguilar, at the Universidad Autónoma de Tamaulipas. The authors also thank to Dr. Miguel Ángel Domínguez Muñoz for the detailed review of the English translation.

\section{Competing interests}

The authors declare that they have no competing interests.

\section{Availability of data and materials}

Datasets are available upon request; please contact jsalinasc@hotmail.com.

\section{Ethics approval}

All procedures involving animal care and management were in accordance with and approved by the Bioethics Committee of the Facultad de Medicina Veterinaria y Zootecnia, Universidad Autónoma de Tamaulipas.

\section{Funding}

Financial support to this research was provided by the Universidad Autónoma de Tamaulipas and the Universidad Autónoma de Baja California, for research leading to a doctoral degree (Fidel Infante-Rodríguez).

Received: 28 April 2016 Accepted: 27 October 2016

Published online: 09 November 2016 


\section{References}

Aftab U (2009) Response of broilers to practical diets with different metabolizable energy and balanced protein concentrations. Braz J Poult Sci 11:169-173

AOAC (1990) Official methods of analysis, 15th edn. Association of Official Analytical Chemists, Arlington

Branson A, Hernández G (2012) Mexico-poultry and products semi-annual sector integration and strong demand continue, in global agricultural information network. http://gain.fas.usda.gov/Recent\%20GAIN\%20 Publications/Poultry\%20and\%20Products\%20Semi-annual_Mexico\%20 City_Mexico 3-20-2012.pdf. Accessed 16 Oct 2015

Corduk M, Ceylan N, Ildiz F (2007) Effects of dietary energy density and L-carnitine supplementation on growth performance, carcass traits and blood parameters of broiler chickens. S Afr J Anim Sci 37:65-73

Duarte KF, Junqueira OM, Borges LL, Rodrigues E, da Filardi RS, Praes MFFM, de laurentiz AC, de Domingues CHF (2014) Performance, carcass traits, and body composition of broilers fed different linseed oil levels between 21 and 56 days of age. Braz J Poult Sci 16:55-60

Ferreira GD, Pinto MF, Neto MG, Ponsano EH, Goncalves CA, Bossolani IL, Pereira AG (2015) Accurate adjustment of energy level in broiler chickens diet for controlling the performance and the lipid composition of meat. Cienc Rural 45:104-110

Gómez-Rosales S, de Angeles ML, Ramírez-Rodríguez E (2012) Productivity and efficiency of nitrogen and energy use in broiler chickens fed soybean meal or canola meal. Rev Mex Cienc Pecu 3:313-330

Houshmand M, Azhar K, Zulkifli I, Bejo MH, Kamyab A (2011) Effects of nonantibiotic feed additives on performance, nutrient retention, gut $\mathrm{pH}$, and intestinal morphology of broilers fed different levels of energy. J Appl Poult Res 20:121-128

INEGI. Instituto Nacional de Estadística, Geografía e Informática (2006) Sistema para la Consulta del Anuario Estadístico del Estado de Tamaulipas. Accessed 16 May 2015. http://www.inegi.org.mx/est/contenidos/ espanol/sistemas/aee06/estatal/tam/index.htm

Jafarnejad S, Sedegh M (2011) The effects of different levels of dietary protein, energy and using fat on the performance of broiler chicks at the end of the third weeks. Poult Sci 5:35-40

Kim JS, Kwon JT, Harim L, Kim JH, Oh SK, Lee BK, Zheng L, Konkuk Jung MS, An BK, Kan CW (2012) Performance and carcass characteristics of two different broiler strains by different levels of metabolizable energy. Korean $J$ Poult Sci 39:195-205

Marcu A, Vacaru-Opriş I, Marcu A, Nicula M, Dronca D, Kelciov B (2012a) Effect of different levels of dietary protein and energy on the growth and slaughter performance at "Hybro PN+" broiler chickens. Pap Anim Sci Biotechnol 45:424-431

Marcu A, Vacaru-Opriş I, Marcu A, Nicula M, Dronca D, Kelciov B (2012b) The influence of feed energy and protein level on meat quality at "Hubbard F15" broiler chickens. Pap Anim Sci Biotechnol 45:432-439
Marcu A, Vacaru-Opriş I, Dumitrescu G, Marcu A, Petculescu CL, Nicula M, Dronca D, Kelciov B (2013) Effect of diets with different energy and protein levels on breast muscle characteristics of broiler chickens. Pap Anim Sci Biotechnol 46:333-340

Milošević N, Veljić M, Đukić SM, Perić L, Bjedov S (2013) Effect of lighting program and energy level in the ration on the slaughter traits of broilers. Biotechnol Anim Husb 29:607-614

National Research Council (NRC) (1994) Nutrient requirements of poultry, 9th edn. National Academy Press, Washington

Nunes JO, Bertechini AG, de Brito JAG, Makiyama L, Mesquita FR, Nishio CM (2012) Evaluation of cysteamine associated with different energy patterns in diets for broiler chickens. Rev Bras Zootec 41:1956-1960

Orduña-Hernández HM, Salinas-Chavira J, Montaño-Gómez MF, InfanteRodríguez F, Manríquez-Núñez OM, Vázquez-Sauceda ML, Yado-Puente $R$ (2016) Effect of frying fat substitution by vegetable oil and energy concentration on diets for productive performance of broilers. Cienc UAT 10:44-51

Rosa PS, Faria Filho DE, Dahlke F, Vieira BS, Macari M, Furlan RL (2007) Effect of energy intake on performance and carcass composition of broiler chickens from two different genetic groups. Braz J Poult Sci 9:117-122

SAS (2007) User's guide: statistics version 9, 6th edn. SAS Inst., Inc., Cary, NC

Tancharoenrat P, Ravindran V (2014) Influence of tallow and calcium concentrations on the performance and energy and nutrient utilization in broiler starters. Poult Sci 93:1453-1462

Tooci S, Shivazad M, Eila N, Zarei A (2009) Effect of dietary dilution of energy and nutrients during different growing periods on compensatory growth of Ross broilers. Afr J Biotechnol 8:6470-6475

Ullah MS, Pasha TN, Ali Z, Saima Khattak FM, Hayat Z (2012) Effects of different pre-starter diets on broiler performance, gastro intestinal tract morphometry and carcass yield. J Anim Plant Sci 22:570-575

Unión Nacional de Avicultores (UNA) (2015) http://una.org.mx/2015/avicultura-mexicana.html. Accessed 15 March 2015

Waldroup PW, Tidwell NM, Izat AL (1990) The effects of energy and amino-acid levels on performance and carcass quality of male and female broilers grown separately. Poult Sci 69:1513-1521

Wang X, Peebles ED, Zhai W (2014) Effects of protein source and nutrient density in the diets of male broilers from 8 to 21 days of age on their subsequent growth, blood constituents, and carcass compositions. Poult Sci 93:463-1474

Zhai W, Peebles ED, Mejia L, Zumwalt CD, Corzo A (2014) Effects of dietary amino acid density and metabolizable energy level on the growth and meat yield of summer-reared broilers. J Appl Poult Res 23:501-515

Zhao LH, Ma QG, Chen XD, Hu XX, Ji C (2008) Effects of dietary energy levels and lysine levels on performance and carcass characteristics in Arbor Acres Broilers. Chin J Anim Sci 44:35-40

\section{Submit your manuscript to a SpringerOpen ${ }^{\circ}$ journal and benefit from:}

- Convenient online submission

- Rigorous peer review

- Immediate publication on acceptance

- Open access: articles freely available online

- High visibility within the field

- Retaining the copyright to your article

Submit your next manuscript at $\boldsymbol{\nabla}$ springeropen.com 